\title{
Pengaruh Jumlah Ruas Stek pada Beberapa Jenis Media Tanam terhadap Pertumbuhan Tanaman Nilam (Pogostemon cablin Benth.) pada Fase Pembibitan
}

\section{The effect of Cutting Interonode Numbers and Types of Planting Media on The Growth of Patchouli Plant in Seedling Stage}

\author{
Mailiani $^{1}$, Agus Halim ${ }^{1}$, Erita Hayati ${ }^{*}$ \\ ${ }^{1}$ Jurusan Agroteknologi, Fakultas Pertanian, Universitas Syiah Kuala
}

\begin{abstract}
Abstrak. Tujuan dari penelitian ini yaitu untuk mengetahui pengaruh jumlah ruas stek, jenis media tanam dan interaksi jumlah ruas stek dan jenis media tanam terhadap pertumbuhan tanaman nilam. Penelitian ini dilaksanakan di Kebun Percobaan Fakultas Pertanian Universitas Syiah Kuala Darussalam Banda Aceh dari bulan Juni hingga Agustus 2018. Analisis data yang digunakan dalam penelitian ini adalah Rancangan Acak Kelompok (RAK) pola faktorial 3 x 4 dengan 3 ulangan. Faktor yang diamati dalam penelitian ini yaitu jumlah ruas stek dan jenis media tanam. Jumlah ruas stek yang digunakan adalah jumlah stek 4 ruas, 5 ruas dan 6 ruas serta jenis media tanam yang digunakan adalah media tanam kontrol, media tanam campuran biochar sekam padi, media tanam campuran eceng gondok dan media tanam campuran water lettuce. Parameter yang diamati yaitu : pertambahan tinggi tanaman, jumlah daun, jumlah tunas, panjang tunas dan volume akar. Hasil penelitian ini menunjukkan jumlah ruas stek berpengaruh nyata terhadap panjang tunas serta berpengaruh sangat nyata pada volume akar. Jumlah ruas stek terbaik terdapat pada 4 jumlah ruas stek. Jenis media tanam berpengaruh sangat nyata terhadap pertambahan tinggi tanaman 30 dan 60 HST, jumlah daun 30 dan 60 HST, jumlah tunas 90 HST, panjang tunas 90 HST dan volume akar HST serta berpengaruh nyata terhadap jumlah daun 90 HST. Jenis media tanam terbaik terdapat pada media tanam campuran biochar sekam padi. Interaksi antara jumlah ruas stek dan jenis media tanam berpengaruh nyata pada pertambahan tinggi tanaman 90 HST serta berpengaruh sangat nyata terhadap volume akar 90 HST. Interaksi antara jumlah ruas stek dan jenis media tanam terbaik terdapat pada jumlah ruas stek (4 ruas) dan jenis media tanam campuran (tanah, pupuk kandang dan biochar sekam padi).
\end{abstract}

Kata kunci : empat ruas stek, biochar sekam padi dan nilam.

Abstrak. This research aims to determine the effect of cutting internode numbers, types of planting media and interaction of cutting internode numbers and types of planting media on the growth of the patchouli plant. This research carried out at the experimental garden of agriculture faculty, Syiah Kuala University, Darussalam, Banda Aceh from Juni to Agustus 2018. The data analysis that used in this research was Randomized Block Design-Factorial 3x4 with 3 replications. The observed factors in this research were cutting internode numbers and types of planting media. The first factor was cutting internode numbers: 4 cutting internode, 5 cutting internode and 6 cutting internode. The second factor was types of planting media: planting media control, mixture planting media of rice husk biochar, mixture planting media of water hyacinth mixture planting media of and water lettuce. The parameters that are observed: plant height increase, leaf numbers, shoot numbers, shoot length, and volume of roots. This result of this research showed that cutting internode numbers were significant on shoot length and very significant in a volume of roots. 4 internode number of cutting showed the best result in the growth of the patchouli plant. Types of planting media were very significant in plant height increase 30 and 60 DAP, leaf numbers 30 and 60 DAP, shoot numbers 90 DAP, shoot length 90 DAP and volume of roots and were significant in leaf numbers 90 DAP. The interaction of cutting internode numbers and types of planting media were significant in plant height increase 90 DAP and very significant in the volume of roots $90 \mathrm{HST}$. 4 internode numbers of cutting and type of mixture planting media (soil, manure, and rice husk biochar) showed the best result on the growth of patchouli plants.

Keyowrds : four cutting internode, patchouli, rice husk biochar

\section{PENDAHULUAN}

Tanaman nilam (Pogostemon cablin Benth.) merupakan salah satu tanaman penghasil minyak atsiri yang penting. Minyak nilam juga digunakan sebagai bahan pengikat minyak wangi, kosmetika, pembuatan obat atau farmasi. Berdasarkan manfaat yang tersebut di atas maka tanaman nilam menjadi salah satu komoditi yang ikut menyumbang devisa lebih dari 50\% dari total ekspor minyak atsiri Indonesia (Ditjen Perkebunan, 2006).

Permasalahan yang dihadapi dalam budidaya tanaman nilam saat ini yaitu produktivitas nilam nasional semakin menurun, sebanyak $45 \%$ total areal pertanian nilam di 
Indonesia produksi yang dicapai hanya berkisar $<150 \mathrm{~kg} \mathrm{ha}^{-1}$ disebabkan oleh beberapa faktor yaitu budidaya nilam di daerah yang kurang sesuai, diakibatkan oleh adanya gangguan penyakit pada tanaman nilam, serta perawatan dalam budidaya yang kurang baik (Setiawan, 2013). Upaya untuk meningkatkan produktivitas nilam salah satu diantaranya dengan memperbaiki kualitas bibit dan peremajaan serta teknik budidaya nilam secara intensif dengan menggunakan bibit yang baik (Insan, 2013).

Nilam Aceh tidak menghasilkan biji sehingga untuk memenuhi kebutuhan bibit nilam dalam jumlah banyak sering dilakukan perbanyakannya dengan cara stek. Penanaman stek langsung di kebun membutuhkan banyak bahan stek karena tingkat kematian stek tanaman lebih tinggi sehingga untuk menghemat penggunaan bahan stek perlu dilakukan dengan cara pembibitan sehingga kebutuhan bahan stek dapat terpenuhi (Insan, 2013).

Bahan stek yang akan digunakan dalam pembibitan harus sehat, kekar dan mempunyai pertumbuhan akar dan tunas yang baik. Pada hasil penelitian Umi et al. (2015) dalam menggunakan jumlah ruas stek 3 ruas, 4 ruas, 5 ruas dan 6 ruas, didapatkan hasil terbaik terhadap pertam-bahan tinggi tanaman dan menghasilkan jumlah daun yang lebih banyak yaitu dengan jumlah ruas stek 4 ruas dan berbeda tidak nyata dengan 5 ruas.

Pembentukan dan perkembangan akar untuk mendukung pertumbuhan stek itu sendiri diperlukan suatu media tanam yang dapat menyediakan atau menyimpan zat cadangan makanan yang dibutuhkan suatu tanaman berupa unsur hara, air, dan mineral yang mendukung pertumbuhan awalnya (Rahardja dan Wiryanto, 2003). Media tanam merupakan faktor eksternal yang dapat mempengaruhi pertumbuhan stek tanaman nilam dan sangat berpengaruh terhadap pertumbuhan awal pembibitan terutama pada pembentukan akar. Media tanam merupakan tempat tumbuh dan berkembangnya akar tanaman.

Beberapa jenis bahan organik yang dapat dijadikan sebagai media tanam diantaranya yaitu biochar sekam padi, eceng gondok (Eichhornia crassipes) dan water lettuce (Pistia stratiotes L.). Berdasarkan hasil penelitian Merlyn (2002) menggunakan media tanam biochar sekam padi memberi pengaruh yang nyata baik terhadap pertumbuhan vegetatif tanaman nilam. Mendukung pendapat Merlyn (2002) bahwa dalam hasil penelitian Basri (2015) menggunakan campuran biochar sekam padi 50\% dan tanah top soil 50\% sebagai media tumbuh pada pembibitan kelapa sawit memberi pengaruh yang baik terhadap pertumbuhan tinggi tanaman.

Menurut Euthalia (2007) tanaman eceng gondok merupakan bahan organik yang dapat dijadikan sebagai media tanam dan pupuk dalam usaha mengatasi ledakan populasi eceng gondok yang sering menjadi masalah di lingkungan perairan. Eceng dapat juga dijadikan sebagai bahan campuran pada media tanam yang mempunyai kandungan nutrisi dan daya serap air yang tinggi. Sejalan dengan hasil penelitian Aini (2013) bahwa penambahan eceng gondok pada media tanam dapat meningkatkan nutrisi yang dibutuhkan oleh jamur, mempunyai pertumbuhan miselium yang lebih cepat, sehingga mempunyai cadangan energi yang cukup untuk menghasilkan berat segar yang optimal.

Husni (2010) menyatakan water lettuce juga dapat dimanfaatkan sebagai sumber organik dalam tanah, dengan demikian tanaman water lettuce dapat dimanfaatkan untuk meningkatkan keseburan tanah dan sekaligus meningkat pertumbuhan tanaman. Water lettuce yaitu tanaman air yang dapat dijadikan sebagai tanaman fitoremediasi yang mampu menyerap logam-logam berat yang mencemari lingkungan perairan. Menurut Arisandi (2006) tanaman water lettuce mengandung beberapa macam mineral yaitu $\mathrm{Na}, \mathrm{K}, \mathrm{Mg}, \mathrm{Ca}$, $\mathrm{Fe}, \mathrm{Cu}, \mathrm{Zn}$, dan $\mathrm{P}$ sehingga sangat berpotensi untuk dijadikan dijadikan sebagai media tanam dan diharapkan mampu meningkatkan pertumbuhan bibit tanaman. 
Penelitian ini dilakukan ingin menindak lanjuti penelitian dari Merlyn (2002) yang menyatakan bahwa media tanam biochar sekam padi dengan campuran tanah dan pupuk kandang perbandingan 2:1:1 memberikan pengaruh yang nyata terhadap pertumbuhan stek tanaman nilam. Serta ingin melakukan perbandingan pada jenis media lain yaitu media eceng gondok dan water lettuce, pada masing-masing jenis media tersebut ditambahkan tanah dan pupuk kandang dengan menggunakan perbandingan yang sama.

\section{METODOLOGI PENELITIAN}

\section{Tempat dan Waktu}

Penelitian ini dilaksanakan di Kebun Percobaan Fakultas Pertanian Universitas Syiah Kuala, Banda Aceh dimulai sejak bulan Juni hingga Agustus 2018.

\section{Alat dan Bahan}

Alat-alat yang digunakan dalam penelitian adalah cangkul, ayakan $\left(0,5 \mathrm{~cm}^{2}\right)$, gelas ukur, gembor, parang, meteran, alat tulis, ember, kertas label, kamera.

Bahan yang digunakan yaitu stek nilam sebanyak 108 stek, ZPT Root-up, fungisida Dithane M-45 $1 \mathrm{~g} / \mathrm{L}$, tanah, pupuk kandang, biochar sekam padi, eceng gondok yang telah dicacah $\pm 1 \mathrm{~cm}$, water lettuce yang telah dicacah $\pm 1 \mathrm{~cm}$, polybag ukuran $29 \times 30 \mathrm{~cm}$ isi 3 $\mathrm{kg}$ sebanyak 108 polybag, dan paranet.

\section{Analisis Data}

Penelitian ini menggunakan Rancangan Acak Kelompok (RAK) pola faktorial $3 \times 4$ dengan 3 ulangan. Faktor jumlah ruas stek terdiri atas 3 taraf yaitu: $R_{1}=4$ ruas, $R_{2}=5$ ruas, dan $R_{3}=6$ ruas. Faktor jenis media tanam terdiri dari 4 taraf yaitu: $M_{1}=\operatorname{tanah}+$ pupuk kandang (2:1), $\mathbf{M}_{2}=$ tanah + pupuk kandang + biochar sekam padi (2:1:1), $\mathbf{M}_{3}=$ tanah + pupuk kandang + eceng gondok $(2: 1: 1)$ dan $\mathrm{M}_{4}=$ tanah + pupuk kandang + water lettuce $(2: 1: 1)$

\section{Persiapan Media Tanam}

Langkah selanjutnya mempersiapkan campuran media tanam dengan menggunakan jenis ember yang sama dengan kapasitas 20 liter. Perlakuan yang diberikan berupa $\mathbf{M}_{1}$ (tanah dan pupuk kandang 2:1) tanah 2 ember dan pupuk kandang 1 ember. Media tanam $\mathbf{M}_{2}$ (tanah, pupuk kandang, biochar sekam padi perbandingan 2:1:1) yaitu tanah sebanyak 2 ember, pupuk kandang 1 ember dan biochar sekam padi 1 ember. Media tanam $\mathrm{M}_{3}$ (tanah, pupuk kandang, eceng gondok perbandingan 2:1:1 yaitu tanah 2 ember, pupuk kandang 1 ember dan eceng gondok 1 ember. Media tanam $\mathrm{M}_{4}$ (tanah, pupuk kandang, water lattuce perbandingan 2:1:1) yaitu tanah 2 ember, pupuk kandang 1 ember dan water lettuce 1 ember. Masing-masing perlakuan campuran media tanam tersebut dimasukkan ke dalam polybag berukuran $29 \mathrm{~cm}$ x $30 \mathrm{~cm}$ dengan kapasitas isi $3 \mathrm{~kg}$. Polybag yang telah berisi media tanam dan diberi label tersebut disusun dengan rapi di bawah rumah atap paranet dan disiram dengan air sebanyak sekali sehari sampai kapasitas lapang dan media tanam digemburkan.

\section{Penanaman Stek Nilam}

Sebelum penanaman stek terlebih dahulu diolesi dengan ZPT Root-up pada. Penanaman stek nilam secara tegak lurus hingga 1 ruas stek masuk ke dalam media tanam. Stek yang digunakan adalah stek pucuk dengan jumlah 4 ruas, 5 ruas dan 6 ruas. Setelah penanaman, bibit nilam disiram dengan air secukupnya. Masa awal persemaian bibit sangat rentan dan belum mampu beradaptasi dengan baik, sehingga bibit mudah stres dan layu sehingga memerlukan naungan untuk menjaga kelembaban. 


\section{Pemeliharaan}

Kegiatan pemeliharaan tanaman yaitu meliputi: penyiangan, pengendalian hama penyakit tanaman, dan penyiraman.

\section{Parameter Pengamatan}

Pengamatan pertumbuhan stek tanaman nilam dilakukan terhadap semua polybag pada masing-masing unit satuan percobaan. Parameter yang diamati terdiri atas:

a. Pertambahan Tinggi Tanaman $(\mathrm{cm})$

Pertamabahan tinggi tanaman diukur dari pangkal batang hingga sampai dengan titik tumbuhnya. Pada saat penanaman terlebih dahulu dilakukan pengukuran pada stek kemudian data pada pengamatan selanjutnya dikurangi data sebelumnya.

b. Jumlah Daun (helai)

Daun yang dihitung yaitu yang telah terbuka secara sempurna.

c. Jumlah Tunas

Tunas yang dihitung yaitu dimulai pada tunas yang tumbuh pada ruas daun pertama awal penanaman hingga ke pucuk.

d. Panjang Tunas $(\mathrm{cm})$

Mengukur tunas mulai dari pangkal tunas sampai titik tumbuh tunas.

e. Volume Akar

Volume akar diukur dengan meng-gunakan gelas ukur yang telah diisi air dan dicatat volume air kemudian akar dimasukkan ke dalam gelas ukur hingga semua bagian akar tenggelam dalam air. Pengukuran dilakukan pada 90 HST dengan mengambil satu sampel pada setiap kombinasi perlakuan. Menghitung

volume akar menggunakan rumus:

Volume akar $=\mathrm{V}_{2}-\mathrm{V}_{1}$

\section{HASIL DAN PEMBAHASAN}

\section{Pengaruh Jumlah Ruas Stek terhadap Parameter Pertumbuhan Bibit Nilam}

Berdasarkan hasil uji $\mathrm{F}$ analisis ragam jumlah ruas stek berpengaruh nyata terhadap parameter panjang tunas dan berpengaruh sangat nyata terhadap parameter volume akar. Parameter panjang tunas didapatkan nilai tertinggi yaitu pada perlakuan 4 ruas yang berbeda nyata dengan perlakuan 6 ruas dan berbeda tidak nyata dengan perlakuan 5 ruas. Hasil terbaik pada parameter volume akar didapatkan pada perlakuan 4 ruas yang berbeda nyata dengan perlakuan 5 ruas dan 6 ruas. Rata-rata nilai semua jenis parameter dapat dilihat pada Tabel 1.

Jumlah ruas stek yang digunakan dapat mempengaruhi pertumbuhan stek. Perlakuan jumlah ruas yaitu 4 ruas, 5 ruas dan 6 ruas, pada perlakuan jumlah 4 ruas berpengaruh nyata bagi panjang tunas dan berpengaruh sangat nyata untuk volume akar. Perlakuan 4 ruas stek berbeda tidak nyata dengan perlakuan 5 ruas. sesuai dengan hasil penelitian Umi et al. (2015) dalam menggunakan jumlah ruas stek 3 ruas, 4 ruas, 5 ruas dan 6 ruas, didapatkan hasil terbaik terhadap pertambahan tinggi tanaman dan memberikan jumlah daun yang lebih banyak yaitu dengan jumlah ruas stek 4 ruas dan berbeda tidak nyata dengan 5 ruas.

Hal ini sejalan dengan hasil penelitian Insan (2013) perlakuan 2 ruas, 3 ruas, 4 ruas dan 5 ruas pada panjang tunas diperoleh hasil terbaik pada perlakuan 4 ruas stek berbeda tidak nyata dengan 5 ruas stek. Hal ini diduga karena pada jumlah ruas stek yang ditanam mempunyai batas tertentu meskipun pada bahan stek tersebut mengandung banyak karbohidrat dibandingkan nitrogen, namun tidak memberikan pertumbuhan yang lebih optimal karena bahan stek dengan jumlah terlalu panjang akan lebih banyak membutuhkan 
energi dalam mempertahankan batangnya. Menurut Kusriningrum (1973) kandungan bahan makanan pada stek nilam terutama protein sangat mempengaruhi pertumbuhan dan perkembangan akar serta tunas tanaman nilam.

Tabel 1. Pengaruh jumlah ruas stek terhadap pertumbuhan bibit nilam

Jumlah Ruas Stek

Parameter

\begin{tabular}{llll}
\hline 4 ruas $\left(\mathrm{R}_{1}\right)$ & 5 ruas $\left(\mathrm{R}_{2}\right)$ & 6 ruas $\left(\mathrm{R}_{3}\right)$ & $\mathrm{BNJ}_{0,05}$ \\
& & & \\
\hline $5,69 \mathrm{~b}$ & $5,04 \mathrm{ab}$ & $3,98 \mathrm{a}$ & 1,31 \\
$25,83 \mathrm{~b}$ & $17,08 \mathrm{a}$ & $16,25 \mathrm{a}$ & 4,15 \\
\hline
\end{tabular}

\begin{tabular}{lllll}
\hline Panjang Tunas $(\mathrm{cm})$ & $5,69 \mathrm{~b}$ & $5,04 \mathrm{ab}$ & $3,98 \mathrm{a}$ & 1,31 \\
Volume Akar $(\mathrm{ml})$ & $25,83 \mathrm{~b}$ & $17,08 \mathrm{a}$ & $16,25 \mathrm{a}$ & 4,15 \\
\hline
\end{tabular}

Keterangan : Angka yang diikuti oleh huruf yang sama pada baris yang sama berbeda tidak nyata berdasarkan uji Beda Nyata Jujur (BNJ) pada taraf $\alpha=0,05$.

\section{Pengaruh Jenis Media Tanam terhadap Pertumbuhan Bibit Nilam}

Hasil uji $\mathrm{F}$ pada analisis ragam menunjukkan bahwa perlakuan jenis media tanam berpengaruh sangat nyata terhadap parameter pertambahan tinggi tanaman 30 dan 60 HST, jumlah daun 30 dan $60 \mathrm{HST}$, jumlah tunas $90 \mathrm{HST}$ panjang tunas $90 \mathrm{HST}$, dan volume akar 90 HST serta berpengaruh nyata terhadap parameter jumlah daun 90 HST. Rata-rata semua jenis parameter dapat dilihat pada Tabel 2.

Tabel 2. Pengaruh jenis media tanam terhadap pertumbuhan bibit nilam

\begin{tabular}{|c|c|c|c|c|c|}
\hline \multirow[b]{2}{*}{ Parameter } & \multicolumn{4}{|c|}{ Jenis Media Tanam } & \multirow{2}{*}{$\mathrm{BNJ}_{0,05}$} \\
\hline & $\left(\mathrm{M}_{1}\right)$ & $\left(\mathrm{M}_{2}\right)$ & $\left(\mathrm{M}_{3}\right)$ & $\left(\mathrm{M}_{2}\right)$ & \\
\hline $\begin{array}{l}\text { Pertambahan Tinggi Tanaman } \\
\text { (cm) } 30 \text { HST }\end{array}$ & $2,35 \mathrm{ab}$ & $3,06 \mathrm{~b}$ & $1,78 \mathrm{a}$ & $2,01 \mathrm{a}$ & 0,82 \\
\hline $\begin{array}{l}\text { Pertambahan Tinggi Tanaman } \\
\text { (cm) } 60 \mathrm{HST}\end{array}$ & 3,98 a & $7,11 \mathrm{~b}$ & 3,85 a & $7,04 \mathrm{~b}$ & 1,99 \\
\hline $\begin{array}{l}\text { Pertambahan Tinggi Tanaman } \\
\text { (cm) } 90 \mathrm{HST}\end{array}$ & 11,72 & 10,35 & 10,78 & 10,16 & - \\
\hline Jumlah Daun (helai) 30 HST & $4,48 \mathrm{a}$ & $6,22 b$ & $3,63 \mathrm{a}$ & $4,26 \mathrm{a}$ & 1,13 \\
\hline Jumlah Daun (helai) 60 HST & $9,96 \mathrm{ab}$ & $11,17 \mathrm{~b}$ & $8,26 \mathrm{a}$ & $8,41 \mathrm{a}$ & 1,96 \\
\hline Jumlah Daun (helai) 90 HST & $15,15 \mathrm{ab}$ & $16,11 \mathrm{~b}$ & $12,93 \mathrm{a}$ & $14,61 \mathrm{ab}$ & 2,58 \\
\hline Jumlah Tunas & $\begin{array}{l}5,83 \mathrm{a} \\
(2,90)\end{array}$ & $\begin{array}{l}8,57 \mathrm{~b} \\
(3,40)\end{array}$ & $\begin{array}{l}5,04 \mathrm{a} \\
(2,70)\end{array}$ & $\begin{array}{l}6,13 \mathrm{ab} \\
(2,92)\end{array}$ & 2,54 \\
\hline Panjang Tunas $(\mathrm{cm})$ & $5,06 \mathrm{ab}$ & $6,10 \mathrm{~b}$ & 3,83 a & $4,62 \mathrm{ab}$ & 1,68 \\
\hline Volume Akar (ml) & $8,67 \mathrm{a}$ & $38,89 \mathrm{c}$ & $8,00 \mathrm{a}$ & $23,33 \mathrm{~b}$ & 2,29 \\
\hline
\end{tabular}

Keterangan : Angka yang diikuti oleh huruf yang sama pada baris yang sama berbeda tidak nyata berdasarkan uji Beda Nyata Jujur (BNJ) pada taraf $\alpha=0,05$.

$\mathrm{M}_{1}$ : Tanah + Pupuk Kandang, $\mathrm{M}_{2}$ : Tanah + Pupuk Kandang + Biochar Sekam Padi,

$\mathrm{M}_{3}$ : Tanah + Pupuk Kandang + Eceng Gondok, $\mathrm{M}_{4}$ : Tanah + Pupuk Kandang + Water

Lettuce. 
Tabel 2 menunjukkan bahwa perlakuan jenis media tanam terbaik pada 30 HST didapatkan pada jenis media tanam tanah + pupuk kandang + biochar yang berbeda nyata dengan media tanam tanah + pupuk kandang + eceng gondok dan media tanam tanah + pupuk kandang + water lettuce, namun berbeda tidak nyata dengan media tanam tanah + pupuk kandang. Sedangkan pada umur 60 HST nilai tertinggi didapatkan pada perlakuan jenis media tanam tanah + pupuk kandang + biochar padi yang berbeda nyata dengan media tanam tanah + pupuk kandang + eceng gondok dan media tanam tanah + pupuk kandang, namun berbeda tidak nyata dengan pelakuan media tanam tanah + pupuk kandang + water lettuce .

Jumlah daun pada 30 HST perlaku-an terbaik yaitu pada jenis media tanam tanah + pupuk kandang + biochar yang berbeda nyata dengan semua jenis media tanam lainnya. Umur 60 HST didapatkan hasil terbaik yaitu pada perlakuan jenis media tanam tanah + pupuk kandang + biochar yang berbeda nyata dengan perlakuan media tanam tanah + pupuk kandang + eceng gondok dan media tanam tanah + pupuk kandang + water lettuce, namun berbeda tidak nyata dengan jenis media tanam tanah + pupuk kandang. Pada umur 90 HST yang terbaik juga di dapatkan pada jenis media tanam tanah + pupuk kandang + biochar yang berbeda nyata dengan media tanam tanah + pupuk kandang + eceng gondok, namun berbeda tidak nyata dengan media tanam tanah + pupuk kandang + water lettuce dan media tanam tanah + pupuk kandang.

Parameter jumlah tunas nilai tertinggi didapatkan pada perlakuan media tanam tanah + pupuk kandang + biochar yang berbeda nyata dengan jenis media tanam tanah + pupuk kandang dan media tanam tanah + pupuk kandang + eceng gondok, namun berbeda tidak nyata dengan perlakuan jenis media tanam tanah + pupuk kandang + water lettuce. Parameter panjang tunas didapatkan hasil tertnggi yaitu pada perlakuan jenis media tanam tanah + pupuk kandang + eceng gondok biochar yang berbeda nyata dengan perlakuan jenis media tanam tanah + pupuk kandang + eceng gondok, namun berbeda nyata dengan perlakuan media tanam tanah + pupuk kandang dan tanah + pupuk kandang + water lettuce . Pada volume akar nilai tertinggi didapatkan pada perlakuan media tanam tanah + pupuk kandang + biochar yang berbeda nyata dengan perlakuan jenis media tanam lainnya.

Hasil penelitian menunjukkan bahwa perlakuan media tanam yang terbaik yaitu pada media tanam tanah + pupuk kandang + biochar yang mampu mendukung pertumbuhan bibit nilam pada beberapa parameter yaitu pertambahan tinggi tanaman, jumlah daun, jumlah tunas, panjang tunas dan volume akar. Demikian juga dengan hasil penelitian Dewi (2004) membuktikan hal yang sama bahwa campuran media tanah, biochar sekam padi dan pupuk kandang dengan perbandingan 2:1:1 pada bibit stum mangga memberikan rata-rata pertumbu-han diameter batang, jumlah daun, jumlah tunas dan volume akar yang lebih baik.

Media tanam tanah + pupuk kandang + biochar diperkirakan selain menyediakan unsur hara bagi tanaman seperti Nitrogen untuk mendukung pertumbuhan vegetatif tanaman juga dapat memperbaiki sifat fisik tanah yaitu bersifat poros sehingga akar lebih mudah menembus media serta pertumbuhan akar lebih luas (volume akar lebih besar) dan perkembangannya lebih optimal. Dengan demikian luas bidang penyerapan untuk akar semakin banyak terutama untuk air dan hara. Fisik tanah yang terbentuk dari suatu media juga merupakan suatu hal yang penting dalam mendukung pertumbuhan awal stek yaitu untuk memacu pertumbuhan dan perkembangan akar tanaman.

Hasil penelitian Merlyn (2002) media tanam campuran tanah, pupuk kandang dan biochar sekam padi mampu memberikan nutrisi bagi bibit nilam dengan cukup yaitu media tersebut menyediakan unsur Nitrogen yang dapat mendukung pertumbuhan vegetatif bibit nilam. Hal ini sejalan dengan hasil penelitian Pratiwi et al. (2017) media tanam biochar sekam padi mempunyai kandungan Nitrogen, Fosfor dan Kalium yang tinggi serta biochar 
sekam padi mampu memperbaiki struktur tanah, mampu menghasilkan jumlah daun yang lebih banyak dan panjang tunas yang lebih baik.

Pertumbuhan vegetatif bibit nilam dari setiap jenis media yang digunakan dalam penelitian ini menunjukkan hasil pertumbuhan bibit nilam yang berbeda-beda, yaitu pada penggunaan media tanam tanah + pupuk kandang + biochar mampu mendukung pertambahan tinggi tanaman, jumlah daun, jumlah tunas sehingga bibit nilam terlihat lebih subur, lebih besar, mempunyai jumlah tunas dan jumlah daun yang lebih banyak dibandingkan dengan jenis media tanam lainnya. Dalam hal ini jenis media tanam berperan penting dalam mendukung pertumbuhan dan perkemba-ngan stek nilam agar mendapatkan hasil yang lebih optimal.

Media tanam tanah + pupuk kandang + biochar mempunyai sirkulasi udara yang tinggi, bersifat ringan dan tidak padat dan mampu mengontrol kelebihan air di dalam tanah sehingga ruang oksigen di dalam media tidak jenuh air. Hal ini diperkuat oleh hasil penelitian sebelumnya Putri (2008) menyatakan bahwa partikel-partikel bahan organik adalah penyusun ruang pori untuk memudahkan penetrasi akar ke dalam tanah. Dengan demikian semakin banyak ruang pori yang terbentuk maka sistem perakaran tanaman akan semakin luas proses penyerapan unsur hara berjalan lebih efektif.

Media tanam tanah + pupuk kandang + biochar selain memberikan pertumbuhan vegetatif yang lebih baik, juga menghasilkan volume akar yang lebih unggul dibandingkan dengan volume akar yang diperoleh dari jenis media tanam lainnya. Akar pada media tanam tanah + pupuk kandang + biochar lebih banyak, panjang dan mempunyai bulu-bulu akar yang banyak sehingga akar lebih banyak kontak dengan tanah dan penyerapan unsur hara lebih optimal, serta hara yang dibutuhkan oleh tanaman untuk pertumbuhannya dapat terpenuhi.

Berdasarkan hasil penelitian Agustin et al. (2014) perkembangan sistem perakaran akan mempengaruhi pertumbuhan tinggi stek dan jumlah daun. Karena akar akan menyerap unsur hara dan air yang diperlukan oleh tanaman untuk pertumbuhannya terutama daun untuk kegiatan fotosintesis, sementara daun menyediakan hasil fotosintesis yang diperlukan untuk pertumbuhan akar dan bagian lainnya.

Pada media tanam tanah + pupuk kandang + biochar tunas lebih cepat muncul dibandingkan pada media tanam lainnya, sehingga media tanam tanah + pupuk kandang + biochar berpengaruh nyata dengan parameter panjang tunas karena memiliki nilai rata-rata yang lebih tinggi.

\section{Interaksi Antara Jumlah Ruas Stek dan Jenis Media Tanam terhadap pertumbuhan Bibit Nilam}

Interaksi antara jumlah ruas stek dan jenis media tanam menunjukkan berpengaruh nyata terhadap parameter pertambahan tinggi tanaman umur 90 HST dan berpengaruh sangat nyata terhadap parameter volume akar.

Parameter pertambahan tinggi tanaman 90 HST perlakuan 4 ruas dengan perlakuan jenis media tanam nilai tertinggi didapatkan pada perlakuan jenis media tanam tanah + pupuk kandang + biochar yang berbeda tidak nyata dengan jenis media tanam tanah + pupuk kandang + water lettuce. Perlakuan 5 ruas jenis media tanam dengan nilai tertinggi didapatkan pada perlakuan jenis media tanam tanah + pupuk kandang yang berbeda tidak nyata dengan tanah + pupuk kandang + eceng gondok. Perlakuan 6 ruas jenis media tanam nilai tertinggi didapatkan pada jenis media tanam tanah + pupuk kandang yang berbeda tidak nyata dengan jenis media tanam tanah + pupuk kandang + eceng gondok.

Perlakuan jenis media tanam tanah + pupuk kandang nilai tertinggi didapatkan pada perlakuan 6 ruas stek yang berbeda tidak nyata dengan perlakuan 4 dan 5 ruas. Perlakuan 
jenis media tanam tanah + pupuk kandang + biochar nilai tertinggi diperoleh pada perlakuan 4 ruas stek dibandingkan dengan nilai yang didapatkan pada 5 dan 6 ruas stek. Media tanam tanah + pupuk kandang + eceng gondok nilai tertinggi di dapatkan pada perlakuan 6 ruas stek yang berbeda tidak nyata dengan 5 ruas stek. Dan perlakuan jenis media tanam tanah + pupuk kandang + water lettuce nilai tertinggi didapatkan pada perlakuan 4 ruas stek yang berbeda nyata dengan nilai perlakuan 5 dan 6 ruas. Nilai rata-rata semua jenis parameter dapat dilihat pada Tabel.

Tabel 3. Rata-rata pertambahan tinggi tanaman dan volume akar bibit nilam akibat perlakuan jumlah ruas stek dan jenis media tanam (90 HST).

\begin{tabular}{|c|c|c|c|c|}
\hline \multirow{2}{*}{ Media Tanam } & \multicolumn{3}{|c|}{ rtambahan Tinggi Tanaman $(\mathrm{cm})$} & \multirow[b]{2}{*}{$\mathrm{BNJ}_{0.05}$} \\
\hline & 4 ruas & 5 ruas & 6 ruas & \\
\hline Tanah + pupuk kandang & $11.67 \mathrm{~A} \mathrm{a}$ & $11.67 \mathrm{~A} \mathrm{a}$ & $11.83 \mathrm{~A} \mathrm{a}$ & \multirow{4}{*}{4,78} \\
\hline $\begin{array}{c}\text { Tanah }+ \text { pupuk kandang }+ \text { biochar } \\
\text { sekam padi }\end{array}$ & $12.89 \mathrm{~A} \mathrm{a}$ & $9.39 \mathrm{~A} \mathrm{a}$ & $8.78 \mathrm{~A} \mathrm{a}$ & \\
\hline $\begin{array}{c}\text { Tanah }+ \text { pupuk kandang }+ \text { eceng } \\
\text { gondok }\end{array}$ & $9.78 \mathrm{~A} \mathrm{a}$ & $11.22 \mathrm{~A} \mathrm{a}$ & $11.33 \mathrm{~A} \mathrm{a}$ & \\
\hline \multirow[t]{2}{*}{$\begin{array}{c}\text { Tanah }+ \text { pupuk kandang }+ \text { water } \\
\text { lettuce }\end{array}$} & $12.56 \mathrm{~A} \mathrm{~b}$ & $9.05 \mathrm{~A} \mathrm{a}$ & $8.86 \mathrm{~A} \mathrm{a}$ & \\
\hline & \multicolumn{3}{|c|}{ Volume Akar (ml) } & $\mathrm{BNJ}_{0.05}$ \\
\hline Tanah + pupuk kandang & $13.33 \mathrm{~A} \mathrm{a}$ & $4.33 \mathrm{~A} \mathrm{a}$ & $8.33 \mathrm{~A} \mathrm{a}$ & \\
\hline $\begin{array}{c}\text { Tanah }+ \text { pupuk kandang }+ \text { biochar } \\
\text { sekam padi }\end{array}$ & $60.00 \mathrm{~B} \mathrm{~b}$ & $23.33 \mathrm{~B} \mathrm{a}$ & $33.33 \mathrm{~B} \mathrm{a}$ & \\
\hline $\begin{array}{c}\text { Tanah }+ \text { pupuk kandang }+ \text { eceng } \\
\text { gondok }\end{array}$ & $10.00 \mathrm{~A} \mathrm{a}$ & $7.33 \mathrm{~A} \mathrm{a}$ & $6.67 \mathrm{~A} \mathrm{a}$ & 12.07 \\
\hline $\begin{array}{c}\text { Tanah }+ \text { pupuk kandang }+ \text { water } \\
\text { lettuce }\end{array}$ & $20.00 \mathrm{~A} \mathrm{a}$ & $33.33 \mathrm{~B} \mathrm{~b}$ & $16.67 \mathrm{~A} \mathrm{a}$ & \\
\hline
\end{tabular}

Keterangan : Angka-angka yang ditandai dengan huruf yang sama (huruf kecil arah baris, besar arah kolom) menunjukkan berbeda tidak nyata berdasarkan uji Beda Nyata Jujur (BNJ) pada taraf $\alpha=0,05$.

Parameter volume akar nilai tertinggi didapatkan pada perlakuan jenis media tanam tanah + pupuk kandang + biochar pada 4 ruas stek yang berbeda nyata dengan jenis media tanam lainnya. Jenis media tanam terbaik pada perlakuan 5 ruas yaitu pada jenis media tanam tanah + pupuk kandang + water lettuce yang berbeda nyata dengan jenis media tanam tanah + pupuk kandang dan tanah + pupuk kandang + eceng gondok, namun berbeda tidak nyata dengan jenis media tanam tanah + pupuk kandang + biochar. Perlakuan 6 ruas jenis media tanam terbaik didapatkan pada jenis media tanam tanah + pupuk kandang + biochar yang berbeda nyata dengan perlakuan jenis media tanam lainnya.

Perlakuan jenis media tanam tanah + pupuk kandang dengan perlakuan jumlah ruas stek terbaik di dapatkan pada perlakuan 4 ruas stek yang berbeda tidak nyata dengan perlakuan 5 dan 6 ruas stek. Perlakuan jenis media tanam tanah + pupuk kandang + biochar sekam jumlah ruas stek terbaik didapatkan pada perlakuan 4 ruas yang berbeda nyata dengan perlakuan jumlah ruas lainnya. Jenis media tanam tanah + pupuk kandang + eceng gondok jumlah ruas stek nilai tertinggi yaitu pada 4 ruas stek yang berbeda tidak nyata dengan perlakuan jumlah ruas stek lainnya. Perlakuan jenis media tanam tanah + pupuk kandang + 
water lettuce jumlah ruas stek terbaik didapatkan pada perlakuan 5 ruas stek yang berbeda nyata dengan perlakuan jumlah ruas 4 dan 6 ruas stek. Terjadi interaksi pada kombinasi perlakuan, berdasarkan hasil penelitian untuk pertambahan tinggi tanaman umur 90 HST pada jumlah ruas stek 4 ruas dan dengan jenis media tanam tanah + pupuk kandang + biochar, kombinasi perlakuan tersebut bisa mendukung pertumbuhan vegetatif bibit nilam yang optimal.

Unsur hara di dalam media diambil oleh akar dan ditranslokasikan ke bagian tanaman lainnya, apabila batang stek lebih panjang maka lebih banyak membutuhkan cadang makanan untuk ditranslokasikan ke semua bagian tanaman sehingga kurang memicu pertumbuhan dan perkembangan tanaman serta diameter batang lebih kecil. Pada kombinasi perlakuan 4 ruas dengan media tanam tanah + pupuk kandang + biochar terlihat bahwa diameter batang lebih besar dan lebih mudah memacu pertumbuhan lainnya seperti tunas, panjang tunas dan jumlah daun karena cadangan makanan terpenuhi secara optimal, maka pertumbuhan dan perkembangan tanaman lebih sehat dan subur.

\section{KESIMPULAN DAN SARAN}

\section{Kesimpulan}

1. Jumlah ruas stek berpengaruh terhadap pertumbuhan bibit nilam yaitu pada panjang tunas dan volume akar. Jumlah ruas stek terbaik yaitu perlakuan 4 ruas.

2. Jenis media tanam berpengaruh terhadap pertumbuhan bibit nilam. Didapatkan hasil terbaik pada perlakuan jenis media tanam tanah + pupuk kandang + biochar , baik terhadap pertambahan tinggi tanaman, jumlah daun, jumlah tunas, panjang tunas dan volume akar.

3. Terdapat interaksi antara jumlah ruas stek dan jenis media tanam pada pertambahan tinggi tanaman 90 HST dan pada volume akar yaitu pada kombinasi perlakuan jumlah 4 ruas stek dengan jenis media tanam tanah + pupuk kandang + biochar.

\section{Saran}

Dari hasil penelitian didapatkan bahwa 4 ruas stek menunjukkan hasil terbaik, sehingga perlu dilakukan penelitian lanjutan mengenai penggunaan ruas stek kurang dari 4 ruas untuk menghemat penggunaan bahan stek. Dan disarankan juga untuk melihat bagaimana bila pupuk kandang pada komposisi 2:1:1 tersebut diganti dengan menggunakan bahan eceng gondok, water lettuce dan campuran keduanya. Alternatif tersebut dapat mengurangi biaya dan penanganan kasus eutrofikasi.

\section{DAFTAR PUSTAKA}

Agustin, A. D., Melya, R. dan Duryat. 2014. Pemanfaatna limbah serbuk gergaji dan arang sekam padi sebagai media sapih untuk cempaka kuning (Michelia champaca). J. $2(3): 49-58$.

Aini, F. N. dan Nengah. D. K. 2013. Pengaruh penambahan eceng gondok (Eichhornia crassipes) terhadap pertumbuhan jamur tiram putih (Pleurotus ostreatus). J. Sains dan seni pomits. Surabaya. 2 (1) : 2337-3520.

Arisandi, D. J. 2006. Pengaruh keberadaan kayu apu (Pistia stratiotes L.) pada pertumbuhan dan hasil tanaman padi sawah (Oryza sativa L.). Skripsi. Fakultas Pertanian. Universitas Brawijaya. Malang. 
Basri, A. B., Chairunnas, dan Abdul, A. 2015. Pengaruh media tumbuh biochar sekam padi terhadap pertumbuhan bibit kelapa sawit. Balai Pengkajian Teknologi Pertanian Aceh. Banda Aceh.

Dewi, S. 2004. Pengaruh penggunaan media tanam terhadap pertumbuhan bibit stum mangga (Mangifera indica L.). J. Budidaya Pertanian. 1 (2): 3-12.

Ditjen Perkebunan, 2006. Nilam. Statistik Perkebunan Indonesia. 19 hal.

Euthalia, H. S. 2007. Pengolahan bahan organik eceng gondok menjadi media tumbuh untuk mendukung pertanian organik. J. (ISSN 1441-318X). Jakarta. 8 (3): 229-234.

Husni, T. S., Agus, S., dan Tristi, I. D. K. 2010. Pengaruh pemberian kayu apu (Pistia stratiotes L.) dan dosis pupuk N, P , K pada pertumbuhan dan hasil padi sawah (Oryza sativa L.). J. Agron. Fakultas Pertanian Universitas Brawijaya. Malang. 38 (3) : 192-198.

Insan Wijaya. 2013. Respon pertumbuhan bibit setek nilam (Pogostemon cablin Benth) dengan perlakuan jumlah ruas dan komposisi media tanam. J. Penelitian Ilmu Pertanian. Fakultas Pertanian Universitas Muhammadiyah Jember. 2 (2): 2-22.

Kusriningrum dan Hardjadi, S.S. 1973. Pembiakan Vegeatif. Agronomi Fakultas Pertanian IPB. Bogor.

Merlyn, M. 2002. Pengaruh media tanam terhadap pertumbuhan setek batang nilam (Pogostemon cablin Benth.). J. Agrica Ekstensia. 11 (1) : 1-8.

Pratiwi, N. E., Bistok, H.S. dan Dina Banjarnahor. 2017. Pengaruh campuran media tanam terhadap pertumbuhan tanaman stroberi (Fragaria vesca I.) sebagai tanaman hias taman vertikal. J. Agric. 29 (1) : 11-20.

Putri, A. I. 2008. Pengaruh media organik terhadap indeks mutu bibit cendana (Santalum album). J. Pemuliaan Tanaman Hutan. 21 (1) : 1-8.

Rahardja, P. C. dan Wiryanto, W. 2003. Aneka Memperbanyak Tanaman. Jakarta: Agromedia Pustaka.

Setiawan dan Rosihan, R. 2013. Produktivitas nilam nasional semakin menurun (45\% total areal pertanaman nilam di Indonesia produksinya kurang dari $150 \mathrm{~kg} / \mathrm{Ha}$. J. Warta Penelitian dan Pengembangan Tanaman Industri, 19 (3): 8-11.

Umi, T., Wijaya, dan Siti, W. 2015. Pengaruh jumlah ruas stek terhadap pertumbuhan bibit nilam (Pogostemon cablin Benth). J. agrogaswati. Cirebon, Jawa Barat. 3 (1) : 259-267. 